\title{
Carrying Capacity of Reusam Aceh Jaya Island Becomes an Ecotourism Area
}

\author{
Izwar $^{1}$ Badaruddin $^{2}$, Miswar Budi Mulya ${ }^{3}$, Robert Sibarani ${ }^{4}$ \\ \{miswarbm_ikl@yahoo.com \\ ${ }^{1}$ Doctoral Program in Natural Resource Management and Environment, Universitas Sumatera \\ Utara, Medan, Indonesia. \\ ${ }^{2,3,4}$ Universitas Sumatera Utara, Medan, Indonesia.
}

\begin{abstract}
This research was carried out in the Reusam Island Tourism Area, Aceh Jaya, with the aim of knowing the specific carrying capacity of the Reusam Island coastal area. Biophysical primary data and slope levels are obtained through measurement and direct observation. Reusam Island has an area of about 22 hectares, which is divided into 4 regions, a shrub area of $14.22 \mathrm{Ha}$, rock cliffs covering an area of $4.63 \mathrm{Ha}$, in addition there is also a fishing area of $1.71 \mathrm{Ha}$, and a sandy beach area as an ecotourism area during this area of 1.4 Ha. Based on the analysis of the beach carrying capacity of Reusam Island, the maximum number of visitors in one day is 264 people, this shows that the carrying capacity has now been exceeded by the number of visitors on Sunday, this will certainly have an impact on environmental degradation such as environmental pollution.
\end{abstract}

Keywords, Ecotourism, Carrying Capacity, Reusam Island, Aceh Jaya

\section{Introduction}

Management of the tourist area with the ecotourism system, has advantages not possessed by other tourist systems, not only enjoying the beauty of nature, but ecotourism also accommodates support for the environment, improves the economic level of the community, and helps local social culture. In accordance with Chiutsi et. al, [6] describes ecotourism in all its forms which is often proposed for environmental preservation while obtaining economic benefits obtained by local communities.

From the exposure of the experts above, in the management and development of ecotourism strongly emphasizes the elements that are directly related to the local community, especially in terms of the especially and the region in general. In this case ecotourism becomes a reliable tool to improve the local economy, especially in disadvantaged areas. In remote and natural areas, ecotourism is responsible for generating income for environmental protection [17].welfare of the community around the location. By involving the community in real ecotourism development and management, it will have a positive influence on improving the economic direction of the community

In a studio conducted by Fennel [10] found resolution 85 of the term ecotourism based on comparative variables, education, culture, benefits for local residents and references to ecotourism sites, specifically in unspoiled areas. Judging from the variables inherent in ecotourism, which are in line with the goals of sustainable development with one of the approaches to bequeath a quality environment for future generations.

Ecotourism was first coined by Hector Ceballos-Lascurain in 1987, namely: Nature tourism or ecological tourism by traveling to natural places that are still not controlled or contaminated (contaminated) with the aim to visit, admire and enjoy the scenery, grow and develop liars, as well as forms of cultural manifestations of society that exist, both from the past and the present [15]. 
Then in the early 1990s it was perfected by the International Ecotourism Society (TIES), which is as follows: Ecotourism is a journey that is responsible for places that are managed with environmental sustainability and improving the welfare of the local population [15]. Understanding ecotourism from time to time enhances development. But in essence, the definition of ecotourism is a form of tourism that is responsible for the preservation of areas that are still natural, provide economic benefits and maintain cultural integrity for local communities [20]

\subsection{Island Ecotourism Activities}

The concept of developing coastal and island tourism areas, differs greatly from the management of tourist areas on the mainland, the island region has its own peculiarities both in terms of its understanding and characteristics. UNCLOS 1982, Chapter VIII article 121 Paragraph 1 which was ratified by the Indonesian government through Law Number 17 of 1985 stated that the island is an area that was built by airia which is equipped by air and which is on the surface of tidal air [14]. The resolution approved by UNCLOS explains the island, which is an ecosystem proposed by the air and designed naturally.

According to de Haas [7] there are three small-scale ecotourism concepts that must be approved, namely environmental sensitivity, socio-cultural feasibility, and economic viability, all three must be symbiotic compatible to achieve sustainability ecotourism. the results of his research at Niue show that the Niue industry only supports environmental and socio-cultural aspects, however, due to insufficient tourist visits, it is not economically feasible.

Judging from de Hass's research, efforts to make an area into a managed ecotourism area must be carried out in a comprehensive manner, not only in accordance with environmental protection, but also in terms of the source of economic income of surrounding communities. Fulfilling the economic needs of the surrounding community will foster a sense of responsibility in environmental care because it is directly related to welfare.

Community-based environmental conservation awareness of the conservation and future of the tourist area. Without community support, the ecosystems in tourism areas are very vulnerable to damage, to understand human relations, especially tourism. Chan [4] discusses how to improve the environment on the island of Penang, a small, highly urban island off the coast of Peninsular Malaysia, and points out various aspects of the island's environment that cannot be restored.

While Redang Island on the mainland is also a pristine island, with abundant coral and clear waters and rich in biodiversity. This is a paradise for divers, but the incredible increase in the number of tourists in this recent evolution has increased the degradation of coral reefs, deforestation and the degradation of genetic quality provided in the environment [5].

One of the actions based on the community, which was carried out by involving the local population as the organizer of the tourism activity, was approved by being a tour guide. The existence of guides is very important in ecotourism activities, because guides play a major role in improving quality

\subsection{Coastal Resources for Ecotourism}

Coastal zones are defined as geomorphological areas on both sides of the coast where biotic and abiotic components of the marine and terrestrial environments interact to form complex ecological and economic resource systems, where human populations, both residents and tourists, carry out their activities. social, recreational and commercial activities (Integrated Coastal Zone Management Protocol in the Mediterranean Sea, 2012). 
The resources contained in the coastal area make it one of the centers of world civilization, so it is not impossible to see, when there was an earthquake and tsunami disaster in Aceh Province, thousands of people became victims, this proves that the coastal area is the center of human life activities. According to Ozyurt and Ergin Coastal areas have historically been used for human settlements because of the abundance of natural resources needed for survival and development [13]

Unspoiled coastal areas, including beaches, dunes, wetlands and forests, provide valuable ecosystem benefits, such as storm surges, recreational opportunities, carbon storage, habitat provision, temperature regulation, and water quality improvement [17]. This protected area can protect the community from the impacts of climate change [2].

While in the United States, which in total, 14.7 million hectares of land covering 15 protected states along the eastern coast of the US, accounted for more than 20 percent of the land area on the east coast [12]. This area protects coastal communities from damage due to climate change, but in fact the coastal areas themselves are receiving the effects of climate change such as rising sea levels. The level of global water level rise averaged 0.13 inches $(3.11 \mathrm{~mm})$ per year between 1993 and 2008, as identified by satellite data [1].

\subsection{Ecotourism as a Regional Development Concept}

Indonesia is blessed with natural beauty and biodiversity. This is very feasible and has a great opportunity to be developed. While the ability of the national economy and the state budget continues to decline in various fields, which forces the government to lend funds in meeting infrastructure development targets. Then the solution by promoting the field of environmentbased tourism to increase the country's foreign exchange is considered appropriate. The increasing ecotourism market potential is a great potential for Indonesia's economic development. This was emphasized by TIES, which began in the 1990s; Ecotourism grows 20-34\% per year [18].

According to Marzouki et. al [11] tourism is one of the sources of regional foreign exchange income, of course this requires effort, preserving the natural environment and protecting various ecosystems in protected areas, must be understood as a prerequisite to attracting tourists, in the end the financial resources derived from tourism depend on such a beautiful environment. A very desirable tourism destination is that tourist expenditure stays among the local population rather than ending up in the US or Europe [18].

Indonesia in general has the potential to become a world tourist destination in various forms, both cultural, natural and religious tourism. For cultural tourism we can see with the diversity of tribes and cultures in Indonesia, one of which is in Jokjakarta, while nature tourism is strongly supported by the natural beauty in Indonesia, such as Bali and NTB. In addition to cultural and natural tourism, the development of religious tourism has also increased, we can see this, one of which is the visit of the people to visit the Kubu Ulama and Canti -anti, as well as historical heritage sites related to religion.

According to Butar and Soemarno [3], Indonesia is a country rich in natural and cultural resources. The country's territory, which consists of more than 17,000 islands stretching along $6400 \mathrm{~km}$ from West to East, and around 3,000 km from North and South, naturally has high diversity. Indonesia has diverse resources such as the availability of the Greater Sunda Islands (Sumatra, Kalimantan, Java and Bali). With its ethnic and cultural diversity, and supported by natural resources, Indonesia has become one of the world tourism destinations, so that in the future development of ecotourism, it will be more optimal, because it is supported by all elements, both the natural environment and government policies 


\section{Method}

The research was conducted in the Reusam Island Tourism area of Rigaih Bay, Lhok Timon Village, Setia Bakti District, Aceh Jaya Regency, Aceh Province, about $4 \mathrm{~km}$ from the Capital District (Calang). The time for conducting the research is planned from August 2018 to July 2019.

The data used in this study consisted of primary data and secondary data. Primary data obtained directly from the field relating to biophysical, social, cultural and economic. Biophysical primary data obtained through measurement and direct observation. In addition, measurements were also carried out to obtain environmental correction factors such as the level of slope of the soil in order to support information on the carrying capacity of Reusam Island.

\subsection{Bearing Capacity Analysis}

The carrying capacity analysis is carried out based on criteria and indicators related to the application of the concept of ecotourism with the following formula:

a. Physical Carrying Capacity (PCC) is the maximum number of visitors physically satisfied with the environment available at a certain time. The PCC formula used and modified from Purnomo [16] is as follows:

$$
P C C \quad=\mathrm{A} \times 1 / \mathrm{B} \times \mathrm{Rf}
$$

Where :

$A=$ Area of area used for tourism

$\mathrm{B}=$ Area required by a tourist to traveled with continued

satisfaction

$\mathrm{Rf}=$ rotation factor

b. Real Bearing Capacity (RCC) is the maximum number of visitors allowed to visit a project with a correction factor (Cf) and is taken from the characteristics of the object applied to the PCC. Correction factor is obtained by considering environmental variables. The modified RCC calculation from Purnomo [16] was carried out with the following formula:

$$
R C C=P C C \times(100-C f 1 / 100)
$$

As for calculating the correction factor $(\mathrm{Cf})$ obtained by considering the variables obtained based on slope class field data on Reusam Island using the following formula:

$$
\mathrm{Cf}=\mathrm{Mi} / \mathrm{Mt} \times 100 \%
$$

Where: $\mathrm{Mi}=$ limit of variable magnitude $\mathrm{Mt}=$ total variable limit

$\checkmark$ RCC correction factors in the form of a slope index. 
In finding the slope factor (ITK), by classifying the slope value based on the slope class as in Table 1 as follows

\begin{tabular}{ccc} 
Table 1. Grade of slope and the value of the slope score \\
\hline Class & Slope $(\%)$ & Classification \\
\hline I & $0-8$ & Flat \\
II & $>8-15$ & Sloping \\
III & $>15-25$ & A little steep \\
IV & $>25-45$ & Steep \\
V & $>45$ & Very steep \\
\hline & Decree of Minister of Agriculture No. $837 /$ KPTS/UM/11/1980
\end{tabular}

c. Effective Carrying Capacity (ECC) is the maximum number of visits but the object is maintained at the available management level. Management capacity is the sum of all conditions in protected areas that can be functioned objectively and in accordance with the objectives of area management, [8]. Management capacity is limited by criteria: the management system, the number of management staff with calculations modified from Purnomo [16] as follows:

$$
\mathrm{ECC}=\mathrm{RCC} \mathrm{x} \text { correction factor }(\mathrm{MC})
$$

MC (Management Capacity) is the number of area management officers.

$$
\begin{aligned}
& M C \quad=\mathrm{Rn} / \mathrm{Rt} \times 100 \% \\
& \text { Where : } \\
& \mathrm{RCC}=\text { Real Carrying Capacity } \\
& \mathrm{Rn}=\text { active resource at the location } \\
& \mathrm{Rt}=\text { number of fixed resources managers }
\end{aligned}
$$

\section{Results and Discussion}

Based on geographical conditions, Reusam Island is very close to the center of government and the economy in Aceh Jaya Regency. with the Capital District only about $8 \mathrm{~km}$. The island of Reusam is directly bordered by the rigah bay to the north, the west is bordered by the village of Lhok Timon, the east is directly bordered by Calang City, the capital of Aceh Jaya Regency, and the south is bordered by the Indian Ocean.

Based on the island's topography, Reusam Island is included in the category of very small islands, with an area of about 22 hectares, which are divided into 4 regions, shrub area has an area of $14.22 \mathrm{Ha}$, cliffs or rock area has an area of $4.6 \mathrm{Ha}$, in addition to that there is a coral reef area which is a fishing area for those who are interested, has an area of $1.71 \mathrm{Ha}$, and the last is a sandy beach area, which is a tourist area, which has an area of $1.4 \mathrm{Ha}$.

In terms of the slope of the cliff, Reusam Island, has no steep or very steep areas, so the height of the cliff is not a threat to tourists. The highest category is somewhat steep, which has an area of about $0.58 \%$ of the island, while the rest is flat and flat, ramps have an area of $21.33 \%$ and flat has an area of $78.09 \%$ of the total island of Reusam.

The carrying capacity analysis is carried out based on the criteria and indicators related to the application of the concept of ecotourism on Reusam Island.

\subsection{Support Physical Carrying Capacity (PCC)}


Physical Carrying Capacity (PCC) is the maximum number of visitors physically satisfied with the environment available at a certain time. To find out the physical carrying capacity, there are some basic assumptions that must be known including:

a. The area of the coast of Reusam Island is a tourist area of 1.4 hectares or $14,000 \mathrm{~m}^{2}$

b. End space requirements for trips around $60 \mathrm{~m}^{2}$ [9]

Rf. The time used for one visit cycle is 3 hours

The area is open around 9 hours per day, starting at $8.30 \mathrm{hrs}$ to $17.30 \mathrm{hrs}$

With the calculation of the carrying capacity as below:

$$
\begin{aligned}
P C C & =\mathrm{A} \times 1 / \mathrm{B} \times \mathrm{Rf} \\
\mathrm{B} & =60 \mathrm{~m}^{2} \\
\mathrm{Rf} & =3 \\
& =14.000 \\
& =14.000 \times 1 / 60 \times 3=700
\end{aligned}
$$

From the total physical carrying capacity analysis, it was found that the number of tourists who could be on Reusam Island in one day was 700 people.

\subsection{Support Real / Real / Real Caring Capacity (RCC)}

Real Bearing Capacity (RCC) is the maximum number of visitors allowed to visit a project with a correction factor (Cf) and is taken from the characteristics of the object applied to the PCC. The correction factor is obtained by considering the environmental slope variable. The modified RCC calculation from Purnomo [16] was carried out with the following formula:

$$
R C C=P C C \times(100-\mathrm{Cf} / 100)
$$

As for calculating the correction factor (Cf) obtained by considering the variables obtained based on slope class field data on Reusam Island, slope class data is derived from Terra SAR-X DSM (Digital Surface Model) data with a spatial resolution of 7.5 meters, sourced from Geospatial information agency (BIG).

Table 2. The correction factor index for the slope grade of Reusam Island

\begin{tabular}{cccccc}
\hline Class & Slope (\%) & Classification & Area (\%) & $\begin{array}{c}\text { Score } \\
\text { Value }\end{array}$ & Slope level index \\
\hline I & $0-8$ & flat & $78,09 \%$ & 20 & 15,61 \\
II & $>8-15$ & Landai & $21,33 \%$ & 40 & 8,53 \\
III & $>15-25$ & Rather steep & $0,58 \%$ & 60 & 0,34 \\
IV & $>25-45$ & Steep & $0 \%$ & 80 & 0 \\
V & $>45$ & Very steep & $0 \%$ & 100 & 0 \\
& & Amount & & & 24,48 \\
\hline
\end{tabular}

Based on Decree of Minister of Agriculture No. 837/KPTS/UM/11/1980. Data source: PRPIDS Unsyiah. 
So that the real carrying capacity with the slope correction factor is:

$$
\begin{aligned}
R C C & =P C C \times((100-\mathrm{Cf}) / 100) \\
& =700 \times((100-24,48) / 100) \\
& =700 \times(75.52 / 100) \\
& =528
\end{aligned}
$$

Whereas slope class maps are processed using ArcGIS software version 10.3 with AcrToolbox 3D Analyst Tools.

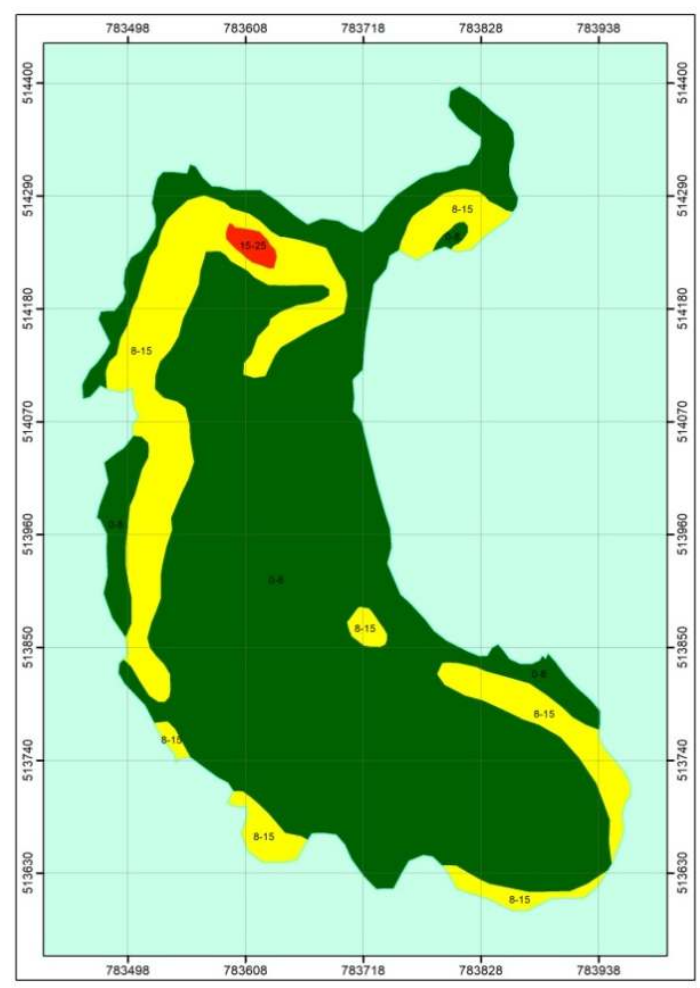

Picture. 1. Map of the slopes of Reusam Island

\subsection{Effective carrying capacity (ECC)}

Effective Carrying Capacity (ECC) is the maximum number of visits but the object is maintained at the available management level. Management capacity is the sum of all conditions in protected areas that can be functioned objectively not in accordance with the objectives of area management, [8]. Management capacity is limited by criteria: Management system, number of management staff with modified calculations from Purnomo [16] as follows: 


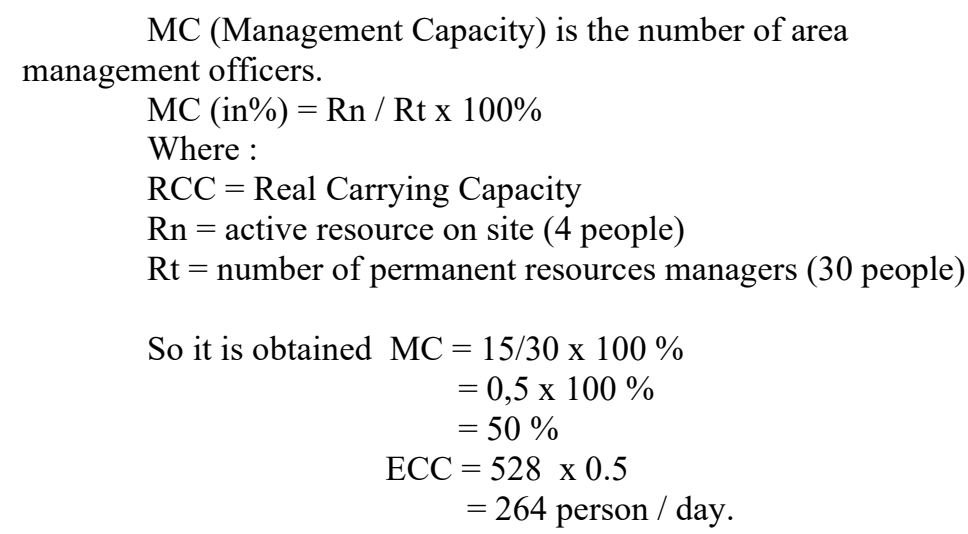

Based on the above analysis, it was found that, the maximum number of visitors in one day was 264 people. This shows that the current carrying capacity has been exceeded by the average number of visitors on Sunday, this will certainly have an impact on environmental degradation such as waste pollution, such as the current situation. From the total number of visitors who can visit the Reusam Island, there are still other factors to consider, including the readiness of adequate transportation facilities, so that it is safe and comfortable for all people, and in accordance with the rules of applying Islamic Sharia in the process of crossing to and from Reusam Island.

In addition to the transportation element, another consideration is the readiness of other facilities such as worship facilities and other attractions that are suitable and support the concept of sharia ecotourism. as complained by one of the visitors about worship facilities that are not in accordance with the concept of sharia namely sister Ainun Mardhiah (26 years) said: the management of Reusam Island is not in accordance with the application of Islamic Sharia because the facilities are still lacking so that it is not separate between men and women both in the facilities worship and beach activities.

Seeing the complaints of visitors above, one of the things that needs to be done is to create a zoning system, both for religious facilities and baths. For religious facilities, it should be done a separation between men and women, besides that worship facilities are also provided for religions other than Islam, because Reusam Island is intended for all groups and religions.

As for bathing attractions, it should be divided into 3 (three) zones, the first 1). Bathing areas for children and families, 2). Women's bathing areas and 3) men's bathing areas. The concept of zoning is also in accordance with the statement of the Head of the Tourism District of Aceh Jaya which states: we need to repair the Mushala, because it is small, besides the more important place of bathing, in the future we will try to separate the bathing places of men and women to be in accordance with the rules the application of Islamic Sharia and we will adjust it later to the law. This was also agreed by the Head of the Aceh Jaya Islamic Sharia Office on the management of Reusam Island that still needed to be improved so that it was in line with Qanun Rule Number 6 of 2014 concerning jinayah law, especially in terms of supervision.

In order to support the sharia concept, of the 264 people who can visit Reusam Island at the same time, a priority must be made of priority through the attractions and entertainment 
facilities provided on the island, so that there are distinct characteristics for visitors who come. As conveyed by the Head of Aceh Jaya Tourism namely, because it is based on sharia, we prioritize family, more family recreation (Father, Mother and child), we conceptualize these three people can enjoy, for children we offer children's games, for mothers we offer a variety of culinary while watching the children, while the fathers we are more directed to fishing. So that all family members can enjoy the situation on the island of Reusam, including we provide restaurants and other attractions.

\section{Conclusions}

Reusam Island is included in the category of very small island, with an area of about 22 hectares, which is divided into 4 regions, shrub area has an area of $14.22 \mathrm{Ha}$, cliffs or rock area has an area of 4.6 Ha, in addition there are also reef areas which is a fishing area for those who are interested, has an area of $1.71 \mathrm{Ha}$, and the last is a sandy beach area, which is a tourist area, which has an area of $1.4 \mathrm{Ha}$. Based on the condition of the island, the maximum number of visitors in one day is 264 people. This shows that the current carrying capacity has been exceeded by the average number of visitors on Sunday, of course this will have an impact on environmental degradation such as waste pollution, such as conditions currently. In addition, the total number of visitors who can visit the Reusam Island, there are still other factors that are taken into consideration, including the readiness of adequate transportation facilities, so that it is safe and comfortable for all people, and in accordance with the rules of applying Islamic Sharia in the process of crossing to and from the island Reusam

\section{References}

[1] Ablain, M., Cazenave, G. Valladeao, and S. Guinehut. A New Assessment Of The Error (2009).

[2] Arkema, K.K,. Guannel, G,. Verutes, H,. Wood, S.A,. Guerry,. Ruckelshaus, M,. Kareiva, P,. Lacayo, M,. Silver, J.M. Coastal Habitats Shield People And Property From Sea Level Rise And Storms. Nat. Clim Change 3 (10), 913e918 (2013)

[3] Butar, b and Soemarno. Environmental Effects Of Ecotourism In Indonesia. Journal of Indonesian Tourism and Development Studies E-ISSN : 2338-1647 (2013)

[4] Chan, N.W. Penang Island: Hill Development and Impacts On the Environment. Teh, T.S. (Ed.). Islands in Malaysia: issues and challenges: 139 - 150. Kuala Lumpur: University of Malaya (2000).

[5] Chan, N.W. Ecotourism and Environmental Conservation in Small Islands in The East Coast of Peninsular Malaysia. Malaysian Journal of Environmental Management 10 (2) 53-69 (2009)

[6] Chiutsi, S,. Mukoroverwa, M, Karigambe, P,. and Mudzengi,BM. The Teory and Practice of Ecotourism in Southern Afrika. Journal of Hospitality Management and Tourism Vol. 2(2) pp. 14-21 (2011). 
[7] De Haas, H.C. 2003. Abstract, Sustainability of Small-Scale Ecotourism: The Case of Niue, South Pacific. Journal Current Issues in Tourism . Volume 5, 2002 - Issue3-4, Dikutip dari http://www.tandfonline.com/doi/abs/10. 1080/13683500 208 667927. pada 30 Mei 2017.

[8] Fandeli, C dan Mukhlison. Ecotourism Exploitation. UGM. Yogyakarta (2000)

[9] Fandeli. C., \& Muhammad. Basic Principles of Conserving Landscapes. Gajah Mada University Press. Yogyakarta (2009).

[10] Fennel DA. A Content Analysis of Ecotourism Definitions. Curr. Iss. Tourism, 4(5): 403$421(2001)$

[11] Marzouki, M,. Froger, G,. and Ballet,J,. Ecotourism Versus Mass Tourism. A Comparison of Environmental Impacts Based on Ecological Footprint Analysis. Journal Sustainability, 4, 123140 / ISSN 2071-1050 (2012)

[12] Niell, R,E,. Kousky, C,. Thompson, A,. Walls, M. Threatened protection: Sea level rise and coastal protected lands of the eastern United States. Ocean \& Coastal Management 137. 118 130 (2017)

[13] Ozyurt, G and Ergin. A. Application Of Sea Level Rises Vulnerability Assessment Model To Selected Coastal Areas Of Turkey. Journal of coastal research ISSN 0749-0258 (2009).

[14] Peuru, g. Development of Ecotourism on Lingayan Island as the Outermost Island. [Dissertation]. Bogor Agricultural University Postgraduate School (2012)

[15] Priyono, Y. Community Based Bukit Tangkiling Ecotourism Development. Journal of Architectural Perspectives. Volume (7) 1 (2012).

[16] Purnomo, H. Kajian Potensi Dan Daya Dukung Ekowisata Dikawasan Cagar Alam Pulau Sempu Jawa Timur [Tesis]. ITB, Sekolah Pascasarjana. (2013).

[17] Santarem, F,. Silva, R,. Santos, P. Assessing Ecotourism Potential Of Hiking Trals: Framework To Incorporate Ecological And Cultural Textures And Seasonality. Tourism manage Perspect. 190-206 (2015)

[18] Situmorang, D, B and Mirzanti, I, R. Social Entrepreneurship to Develop Ecotourism. International Conference On Small and Medium Enterprises Development With a Theme "Innovation and Sustainability In Sme Development" (ICSMED 2012). Procedia Economics and Finance (4) 398 - 405. (2012).

[19] Spalding, M,. Ruffo, S,. Lacambra, C,. Meliane, I,. Hale, L.Z,. Shepard, C.C,. Beck, M.W. The Role Of Ecosystems In Coastal Protection: Adapting To Climate Change and Coastal Hazards. Ocean coast Manag. (90) 50-57 (2014).

[20] Wunder S. Ecotourism and Economic An Empirical Approuch. Ecological Economics. 29:465-479 (2000). 